\title{
Solid Phase Extraction Based on the Use of Thermophilic Bacteria Bacillus aerius VO-8 Immobilized XAD-16 for The Preconcentrations of $\mathrm{Co}$ and $\mathrm{Ni}$
}

\author{
Veysi Okumuş, and Ersin Kılınç
}

\begin{abstract}
Bacillus aerius VO-8 (Accession:KJ842091.1), a thermophilic bacteria, was immobilised on Amberlite XAD-16 and used as solid phase biosorbent for preconcentrations of $\mathrm{Co}$ (II) and $\mathrm{Ni}$ (II) before their determination by inductively coupled plasma optical emission spectrometry (ICP-OES). Effect of various parameters such as $\mathrm{pH}$, flow rate of the sample solution, amount of the biosorbent, type of eluent and reusability of column were investigated. For $\mathrm{Co}$ and $\mathrm{Ni}$ the optimum $\mathrm{pH}$ values, flow rate and type of eluent were found $\mathrm{pH} 6.0$ and $5.0,2 \mathrm{ml} / \mathrm{min}, 1.0 \mathrm{~mol} / \mathrm{L} \mathrm{HCl}$, respectively. Maximum biosorption capacity was observed $13,8 \mathrm{mg} / \mathrm{g}$ for Co and $10.5 \mathrm{mg} / \mathrm{g}$ for Ni. The accuracy of the proposed method was verified through the analysis of certified reference samples of tea (NCS ZC-73014) and applicability of the method was validated through the concentrations of $\mathrm{Co}$ and $\mathrm{Ni}$ were determined in some edible vegetables.
\end{abstract}

Index Terms - Preconcentration, Bacillus aerius, XAD16, biosorption,

\section{INTRODUCTION}

Heavy metals are major pollutants in marine, ground, industrial and even treated wastewaters [1]. There are several physicochemical tratment technologies used in the removal of heavy metals. These conventional methods include solid phase extraction, precipitation, ion exchange, reverse osmosis, electrochemical processes, cloud point extraction and membrane processes [2]. Among them, SPE has some advantages compared with other methods, such as reduced solvent usage, no use of toxic organic solvents, low disposal costs and short experimental times [3].

The use of biological materials for removing and recovering heavy metals from contaminated industrial effluents has emerged as a potential alternative method to conventional techniques [4]. In recent times, the method of removal of metallic ions from liquid effluents with the help of microorganisms has received greater attention over the conventional physical/chemical methods [5].

In the present work, we focused on the development of a sensitive and selective preconcentration method. Bacillus aerius was used as the bacterial biomass for the preconcentration of $\mathrm{Co}$ and $\mathrm{Ni}$ prior to its determination by

V.Okumus is now Department of Biology, Faculty of Art and Science, University of Siirt, TR-56100 Siirt, Turkey

E.Kilinc is now Medical Laboratory Techniques, Vocational Higher School of Healthcare Studies, Mardin Artuklu University, 47200 Mardin, Turkey
ICP-OES. Critical parameters in SPE experiments were optimized.

\section{MATERIAL AND METHODS}

\section{A. Instrumentation}

The concentrations of metal ions were determined by ICP-OES (Perkin-Elmer Optima 2100 DV; Shelton CT). SPE experiments were performed on polypropylene column $(1.0 \mathrm{~cm}$ $\mathrm{x} 10.0 \mathrm{~cm}$ ).

\section{B. Reagents and Solutions}

Standard solutions of $1000 \mathrm{mg} / \mathrm{L} \mathrm{Co}$ and Ni were diluted to prepare working standards. Certified reference tea sample was obtained from China National Analysis Center for Iron and Steel Amberlite XAD-16 (Sigma Chemical, St. Louis, MO, USA) was used as a support material for the immobilization of Bacillus aerius. $\mathrm{pH}$ was adjusted by the addition of diluted $\mathrm{HCl}$ or $\mathrm{NaOH}$ to sample solution.

\section{Preparation of SPE Column}

Thermophilic bacteria was isolated from hot-spring water of Norsin, Bitlis in Turkey, was used as biosorbent in this study. It was cultivated in 500-ml Erlenmeyer flasks containing $100 \mathrm{ml}$ Nutrient Broth (NB) medium by shaking at $50{ }^{\circ} \mathrm{C}$ for $36 \mathrm{~h}(150$ $\mathrm{rpm})$. The cultures were centrifuged at $8,000 \mathrm{rpm}$ for $7 \mathrm{~min}$, and then the pellets were washed with $0.9 \% \mathrm{NaCl}$ and dried in an oven at $80{ }^{\circ} \mathrm{C} 24 \mathrm{~h}$. To obtain a fine powder of the dried cells, they were ground in a porcelain mortar and then were autoclaved at $121^{\circ} \mathrm{C}$ for $15 \mathrm{~min}$ to assess complete death of the dried cells. Finally, the cells were inoculated to liquid medium, and the absence of any growth indicated positive results (complete death of the bacteria). Dry biomass powder $(200 \mathrm{mg}$ ) was mixed with $800 \mathrm{mg}$ of Amberlite XAD-16 and $5 \mathrm{ml}$ of distilled water and then thoroughly mixed [6,7]. Samples were collected along the cultivated banks of the Botan River (Siirt, Turkey) and stored in polyethylene bags according to their type and then brought to the laboratory for preparation and treatment. They were first washed with tap water to remove the pollutions from soil and then rinsed by distilled water. Then, they were dried at $80^{\circ} \mathrm{C}$ for $24 \mathrm{~h}$ in oven. The samples were ashed at $480^{\circ} \mathrm{C}$ in a furnace for $3 \mathrm{~h}$, and the ashed samples were dissolved with a mixture of nitric acid-hydrogen peroxide (2:1, $\mathrm{v} / \mathrm{v}) .3 \mathrm{ml}$ of the acid mixture was then added; the process was repeated two times with occasional shaking on a hot plate. After drying, $5 \mathrm{ml}$ of $1 \mathrm{~mol} / \mathrm{L}$ nitric acid was added to dissolve 
the remaining residue. It was then diluted up to $50 \mathrm{ml}$ with distilled water and SPE procedure was applied. The same procedure was also applied to the certified reference tea sample, NCS ZC73014.

\section{RESULTS AND DISCUSSION}

\section{A. Effects of $p H$}

The $\mathrm{pH}$ is one of the most significant empirical parameters in heavy metal biosorption studies that affects the protonation of the active sites on the biomass [8]. All bacteria shows diverse biosorption characteristics at a given $\mathrm{pH}$ owing to differences in the cell wall structure. The effect of $\mathrm{pH}$ on SPE of Co and $\mathrm{Ni}$ by immobilized thermophilic Bacillus aerius is showed in Fig. 1. To study the influence of $\mathrm{pH}$, a series of experiments were performed using $50.0 \mathrm{ml}$ of $10 \mu \mathrm{g} / \mathrm{L} \mathrm{Co}$ and $\mathrm{Ni}$, with different $\mathrm{pH}$ from 2.0 to 8.0. The optimum $\mathrm{pH}$ was found to be 6.0 for $\mathrm{Co}$ and 5.0 for Ni. After this result, all the subsequent biosorption studies were performed at $\mathrm{pH} 6.0$ and 5.0 for $\mathrm{Co}$ and $\mathrm{Ni}$, respectively.

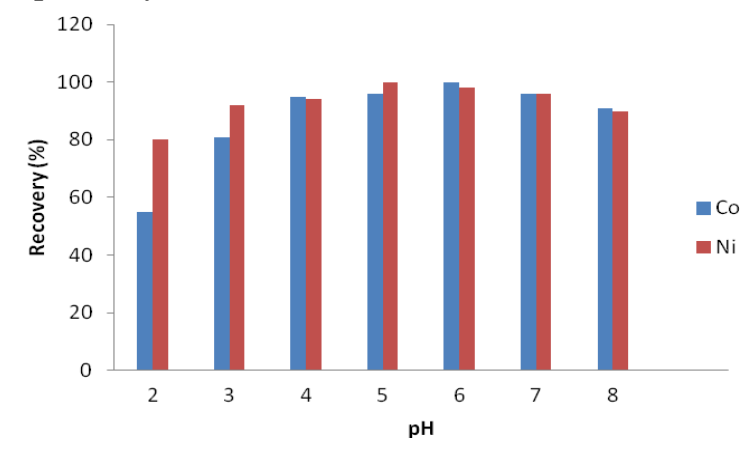

Fig. 1. Effect of $\mathrm{pH}$ on solid phase extraction of $\mathrm{Co}$ and $\mathrm{Ni}$

\section{B. Effects of flow rate}

The effect of flow rate on recoveries of $\mathrm{Co}$ and $\mathrm{Ni}$, from aqueous solution by immobilized thermophilic Bacillus aerius onto XAD16 was investigated. $50.0 \mathrm{ml}$ of $10 \mu \mathrm{g} / \mathrm{L}$ Co and $\mathrm{Ni}$ was adjusted to the optimum $\mathrm{pH}$ value. Then, these solutions were passed from the bacteria immobilized column with flow rates between 1.0 and $6.0 \mathrm{~mL} / \mathrm{min}$. The quantitative recoveries were obtained at the flow rates $2.0 \mathrm{~mL} / \mathrm{min}$ for both metals (Fig. 2). The flow rate of the sample solution is major parameter affecting both the uptake of the analyte metal ions and controlling the time of analysis [9].

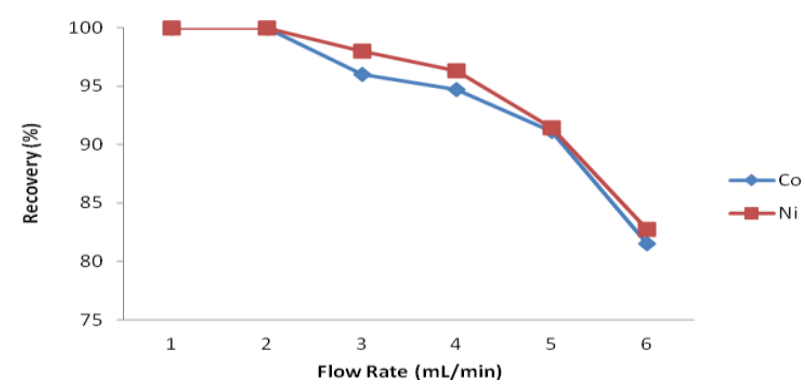

Fig.2. Effect of flow rate on recovery of $\mathrm{Co}$ and $\mathrm{Ni}$

\section{Effects of amount biosorbent and resin}

The preconcentration of $\mathrm{Co}$ and $\mathrm{Ni}$ depending on the amount of biosorbent and resin XAD16 were analyzed in the range of 50-300 $\mathrm{mg}$ and 500-1000 mg for Bacillus aerius and resin, respectively.. Maximum uptake of $\mathrm{Co}$ and $\mathrm{Ni}$ ions was monitored when the amount of biosorbent was $200 \mathrm{mg}$ and resin was $800 \mathrm{mg}$ (Fig. 3,4). Thus, future experiments were carried out using $200 \mathrm{mg}$ of biosorbent and $800 \mathrm{mg}$ of resin XAD16.

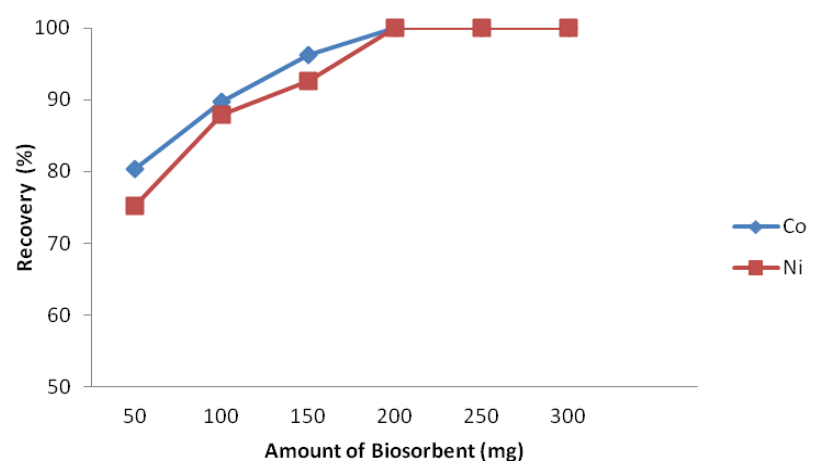

Fig. 3. Effect of amount of biosorbent on recovery of Co and $\mathrm{Ni}$

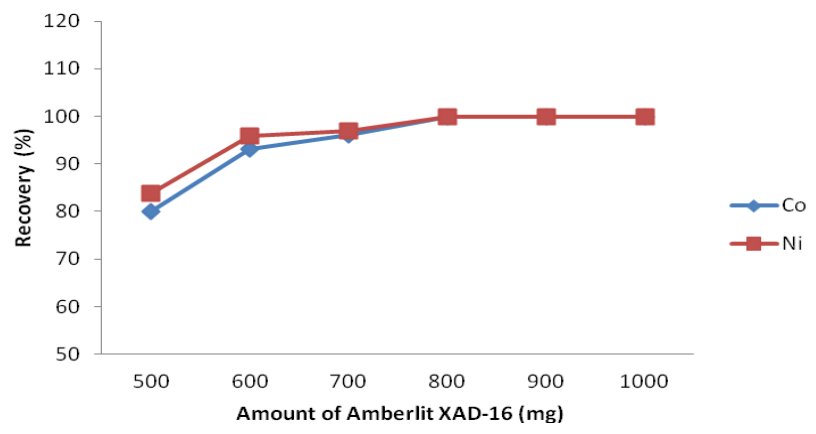

Fig. 4. Effect of amount of resin XAD16 on recovery of Co and $\mathrm{Ni}$

\section{Reusability of solid phase column}

In SPE process, the potential reusability of the column is a very important parameter to evaluate the biosorbent which can guaranty its common application in industry [10]. The stability of the SPE column exhibits that the uptake of $\mathrm{Co}$ and $\mathrm{Ni}$ ions were stable at least 20 biosorption-elution cycles with the recovery for the Co and $\mathrm{Ni}$ ions greater than $96.1 \%$ and $94.5 \%$, respectively (Fig. 5).

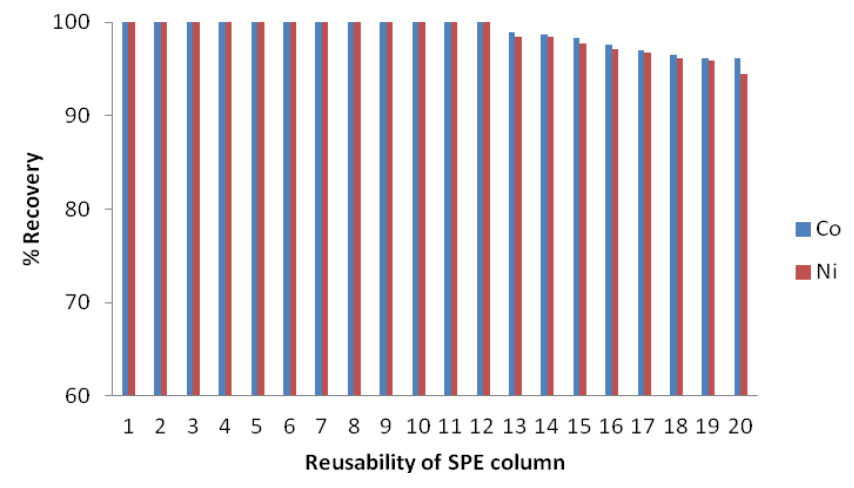

Fig. 5 Reusability of the column for further preconcentration of Co and $\mathrm{Ni}$ 


\section{E. Effect of the type and volume of elution solutions}

$\mathrm{HCl}$ and $\mathrm{HNO} 3$ were investigated as eluent. Variations in recovery values of metal ions with different concentrations and volumes of acids were investigated (Table 1). When concentration of $\mathrm{HCl}$ was increased from 0.5 to $1.0 \mathrm{~mol} / \mathrm{L}$ by a volume of $5.0 \mathrm{ml}$, recovery values of $\mathrm{Co}$ and $\mathrm{Ni}$ increased from $94.1 \%$ to $99.5 \%$ and from $95.6 \%$ to $99.2 \%$, respectively. After this result, all the subsequent experiment were performed $5 \mathrm{ml}$ of $1.0 \mathrm{~mol} / \mathrm{L} \mathrm{HCl}$ was selected as the optimum volume $\mathrm{HCI}$ for elution of both metal ions.

TABLE I

EFFECT Of THE TYPe AND VOLUME Of ELUTION SOLUTIONS ON THE RECOVERY OF CO AND NI

\begin{tabular}{|c|c|c|c|c|}
\hline \multirow{2}{*}{$\begin{array}{l}\text { Type of } \\
\text { elution }\end{array}$} & \multirow{2}{*}{$\begin{array}{c}\text { Volume } \\
(\mathrm{mL})\end{array}$} & \multirow{2}{*}{$\begin{array}{c}\text { Concentration } \\
\text { (mol/L) }\end{array}$} & \multicolumn{2}{|c|}{ Recovery (\%) } \\
\hline & & & $\mathrm{Co}^{2+}$ & $\mathrm{Ni}^{2+}$ \\
\hline & 3.0 & 0.5 & $86.7 \pm 0.5$ & $84.6 \pm 0.4$ \\
\hline \multirow[t]{3}{*}{$\mathrm{HCl}$} & 5.0 & 0.5 & $91.2 \pm 0.8$ & $91.7 \pm 0.3$ \\
\hline & 3.0 & 1.0 & $94.1 \pm 0.7$ & $95.6 \pm 0.5$ \\
\hline & 5.0 & 1.0 & $99.5 \pm 0.4$ & $99.2 \pm 0.8$ \\
\hline \multirow{4}{*}{$\mathrm{HNO}_{3}$} & 3.0 & 0.5 & $81.2 \pm 0.9$ & $83.9=0.8$ \\
\hline & 5.0 & 0.5 & $91.9 \pm 0.6$ & $90.0 \pm 0.7$ \\
\hline & 3.0 & 1.0 & $92.7 \pm 0.9$ & $86.1=0.8$ \\
\hline & 5.0 & 1.0 & $94.1=0.5$ & $93.3 \pm 0.9$ \\
\hline
\end{tabular}

The accuracy of the method was validated by applying the method to the certified reference tea sample (Table 2). The obtained values were found to agree with the certified values. 200 and $400 \mathrm{ng} / \mathrm{g}$ of Co and 1 and $3 \mu \mathrm{g} / \mathrm{g}$ of $\mathrm{Ni}$ were also added to the sample. The results exhibited that spiked amounts of $\mathrm{Co}$ and $\mathrm{Ni}$ were quantitatively recovered. As a result, it can be said that the method can be applied to real samples without the loss of analytes.

TABLE II

THE RESULTS FOR CO AND NI IN CERTIFIED REFERENCE SAMPLES OF TEA LEAVES (NCS ZC-73014), N=3

\begin{tabular}{|c|c|c|c|}
\hline Metal & Added & Certified & Found \\
\hline \multirow{4}{*}{$\mathrm{Co}(\mathrm{ng} / \mathrm{g})$} & - & $220 \pm 20$ & $218.3 \pm 19$ \\
\hline & 200 & - & $409.5 \pm 12$ \\
\hline & 400 & - & $632.4 \pm 26$ \\
\hline & - & $3.4 \pm 0.3$ & $3.3 \pm 0.4$ \\
\hline \multirow[t]{2}{*}{$\mathrm{Ni}(\mu \mathrm{g} / \mathrm{g})$} & 1.0 & - & $4.6 \pm 0.3$ \\
\hline & 3.0 & - & $6.2 \pm 0.4$ \\
\hline
\end{tabular}

The developed method was applied to real vegetable samples collected along the cultivated banks of the Botan River to determine the concentrations of $\mathrm{Co}$ and $\mathrm{Ni}$. The results obtained are shown in Table 3. Concentrations of Co were in the range of $21.52-45.34 \mathrm{ng} / \mathrm{g}$. The highest $\mathrm{Co}$ and $\mathrm{Ni}$ concentration were determined in the purslane and onion, respectively. The lowest $\mathrm{Co}$ and $\mathrm{Ni}$ concentration was determined in the aubergine.
TABLE III

THE LEVEL OF TOTAL CO AND Ni IN VEGETABLES (N=3)

\begin{tabular}{|c|c|c|}
\hline \multirow{2}{*}{ Vegetable } & \multicolumn{2}{|c|}{ Metals } \\
\hline & $\mathrm{Co}(n g / g)$ & $\mathrm{Ni}(\mu \mathrm{g} / \mathrm{g})$ \\
\hline Auberging & $21.52=0.55$ & $1.77 \pm 0.22$ \\
\hline Okra & $39.43=0.92$ & $1.82=0.31$ \\
\hline Onion & $34.55=0.87$ & $6.56 \pm 0.54$ \\
\hline Purslane & $45.34=0.75$ & $3.45 \quad 0.25$ \\
\hline
\end{tabular}

\section{CONCLUSION}

An alternative method was developed for the preconcentration of Co and Ni by solid phase extraction (SPE). Bacillus aerius was used as a bacterial biosorbent for the preconcentration of $\mathrm{Co}$ and $\mathrm{Ni}$ prior to its determination by inductively coupled plasma optical emission spectrometry (ICP-OES). The important experimental parameters in the developed SPE method were optimized. The applicability of the method was validated through the analysis of certified reference tea samples. Results showed that founded concentrations for $\mathrm{Co}$ and $\mathrm{Ni}$ agreed with certified values. Edible vegetables were collected along the cultivated banks of the Botan River. It was also found that the same SPE column can be used 20 times without loss of efficiency.

\section{ACKNOWLEDGMENT}

This study was supported by Scientific Research Projects Unit of Siirt University (Project code: BAP-2011-SIUFED-F3), (Turkey).

\section{REFERENCES}

[1] Ozdemir, S., Okumus, V., Kilinc, E., Bilgetekin, H., Dundar, A., Ziyadanogulları, B., (2012), 'Pleurotus eryngii immobilized Amberlite XAD-16 as a solid-phase biosorbent for preconcentrations of $\mathrm{Cd} 2+$ and Co2+ and their determination by ICP-OES', Talanta. 99 pp. 502-506. http://dx.doi.org/10.1016/j.talanta.2012.06.017

[2] Ahluwalia, S.S., and D. Goyal, (2007), "Microbial and plant derived biomass for removal of heavy metals from wastewater' Bioresour. Technol. 98 pp. 2243-2257.

http://dx.doi.org/10.1016/j.biortech.2005.12.006

[3] Kilinc, E., Dundar, A., Ozdemir, S., Okumus, V. (2013) 'Solid Phase Extraction Based on the Use of Agaricus arvensis as a Fungal Biomass for the Peconcentrations of $\mathrm{Pb}$ and $\mathrm{Al}$ Prior to Their Determination in Vegetables by ICP-OES', Atom. Spectrosc. 34 pp. 78-88.

[4] Okumus, V., Basaran, D., Onay, A. (2010), 'Heavy metals biosorption by submerged aquatic plant Nasturtium officinale"' Asian J. Chem., 22 (1) pp. 455-460 2010.

[5] Ozdemir, S., Kilinc, E. Okumus, V., Poli, A., Nicolaus, B., Romano, I. (2016), 'Thermophilic Geobacillus galactosidasius sp nov. loaded < gamma >-Fe2O3 magnetic nanoparticle for the preconcentrations of $\mathrm{Pb}$ and Cd' Bioresour. Technol., 201 pp. 269-275. http://dx.doi.org/10.1016/j.biortech.2015.11.052

[6] Okumus, V., Ozdemir, S., Kilinc, E. Dundar, A.,Yuksel, U., Baysal, Z. 'Preconcentration with Bacillus subtilis immobilized Amberlite XAD-16: determinations of $\mathrm{Cu} 2+$ and $\mathrm{Ni} 2+$ in river, soil, and vegetable samples", Bioremed. J., 19:1 47-55 2015

[7] Ozdemir, S., Okumus, V., Dundar, A., Kilinc, E. Preconcentration of metal ions using microbacteria. Microchim. Acta, 180: 719-739 2013 http://dx.doi.org/10.1007/s00604-013-0991-x 
[8] Areco, M.M., and M.D.S. Afonso., (2010), 'Copper, zinc, cadmium and lead biosorption by Gymnogongrus torulosus thermodynamics and kinetics studies" Colloid Surf. B 81 pp. 620-628.

http://dx.doi.org/10.1016/j.colsurfb.2010.08.014

[9] Duran, A., M. Tuzen, and M. Soylak, (2009), 'Preconcentration of some trace elements via using multiwalled carbon nanotubes as solid phase extraction adsorbent'” J. Hazard. Mater., 169 pp. 466-471. http://dx.doi.org/10.1016/j.jhazmat.2009.03.119

[10] Kilinc, E., Dundar, A., Ozdemir, S., Okumus, V., (2013), "Preconcentration of Sn in real water samples by solid phase extraction based on the use of Helvella leucopus as a fungal biomass prior to its determination by ICP-OES^^ Atom. Spectrosc. 34 pp. 133-137.

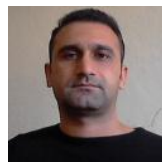

Dr.Veysi Okumus holds Ph.D (April, 2010) in Biotechnology. He is working as a lecturer in faculty of Science and arts in Siirt University,Turkey. His international experience includes various programs, contributions and participation in different countries for diverse fields of study.

Research Interest: Environmental biotechnology, microbial biotechnology.

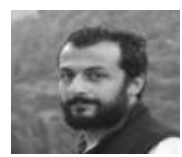

Dr.Ersin Kilinc holds Ph.D (2012) in Analytical Chemistry. He is working as a lecturer in Medical Laboratory Techniques, Vocational Higher School of Healthcare Studies, Mardin Artuklu University, Turkey. His research interests reflect in his wide range of publications in various national and international journals.His works are in Environmental pollution and bioremediation. 